\title{
Performance of Kadaknath Breed of Fowl Under Intensive System of Housing in Malwa Region of Madhya Pradesh
}

\author{
Praveen Dubey $^{1}$, Shrikant Joshi ${ }^{1}$, Laxmi Chouhan ${ }^{1 *}$, M.K. Mehta ${ }^{1}$ and Anil Shinde ${ }^{2}$ \\ ${ }^{1}$ Department of Poultry Science, C.V.Sc. E A.H. Mhow, N.D.V.S.U., Jabalpur, M.P. INDIA \\ ${ }^{2}$ Instructional Dairy Unit, College of agriculture, J.N.K.V.V., Jabalpur, M.P., INDIA \\ "Corresponding author: L Chouhan; E-mail:drlaxmimhow@gmail.com
}

Received: 30 June, 2021

Revised: 10 Sept., 2021

Accepted: 16 Sept., 2021

\begin{abstract}
Study was carried out on 500 straight run chicks of Kadaknath breed of fowl, under intensive system of housing up to 5 months of age. The average daily feed consumption, body weight, body weight gain and feed conversion ratio (FCR) were recorded weekly up to 8 week of age and thereafter at monthly interval up to 5 months of age. The average weight of day old chicks was $28.55 \pm 0.5 \mathrm{~g}$. The mean weekly feed consumption recorded from 1-8 week of age was $21.29 \pm 0.11,46.43 \pm 0.71,82.60 \pm 0.9$, $104.38 \pm 2.09,115.45 \pm 2.66,150.51 \pm 1.17$ and $163.63 \pm 2.99$ and $244.52 \pm 2.62 \mathrm{~g}$, respectively. The overall mean weekly body weight gain from 1-8 week of age was $7.54 \pm 0.10,16.84 \pm 0.44,32.23 \pm 1.87,42.42 \pm 3.23,50.91 \pm 1.22,72.30 \pm 3.36,70.59$ \pm 4.24 and $86.34 \pm 5.65 \mathrm{~g}$, respectively. The corresponding values obtained for FCR were $2.82 \pm 0.35,2.75 \pm 0.09,2.56 \pm 0.05$, $2.46 \pm 0.05,2.26 \pm 0.03,2.09 \pm 0.08,2.32 \pm 0.13$ and $2.84 \pm 0.12$. The weekly body weight gain linearly increased up to eight week. The mean monthly feed consumption during $3^{\text {rd }} 4^{\text {th }}$, and $5^{\text {th }}$ month of age was $1682.09 \pm 38.59,1739.05 \pm 11.84$ and $1622.83 \pm 7.14 \mathrm{~g}$, respectively. The overall mean weight gain recorded at $3^{\text {rd }}, 4^{\text {th }}$, and $5^{\text {th }}$ month of age was $260.52 \pm 7.49,174.58$ \pm 7.50 and $131.41 \pm 18.84 \mathrm{~g}$, respectively. The corresponding values for FCR were $6.46 \pm 0.06,9.97 \pm 0.37$ and $12.56 \pm 1.98$, respectively. The dressing percentage, giblet yield, breast muscle, thigh muscle, abdominal fat and weight of organs (spleen, thymus and bursa) were $70.43 \pm 1.79,5.35 \pm 0.02,19.41 \pm 0.13,14.91 \pm 0.25,1.59$ and $0.88 \pm 0.04$ per cent, respectively of live weight at 5 months of age. An overall mortality of $25.2 \%$ was recorded during entire period of experiment with a maximum of $11.40 \%$ during first week.
\end{abstract}

\section{HIGHLIGHTS}

(0 Economic traits of Kadaknath under intensive system of housing.

(0 To establish feed requirement under intensive system of housing.

(0 Adoptability of Kadkanth birds in malwa region of M.P.

Keywords: Kadaknath fowl, Black meat chicken, Growth rate, Feed Conversion Ratio, Carcass traits

Kadaknath fowl, also called as "Kalamasi" meaning black meat or black flesh, is an inhabitant of Jhabua, Alirajpur and Dhar Districts of Western Madhya Pradesh. This breed is mainly reared by tribal communities of these districts. Some of the important breed characteristics have been established in these birds through many generations of selection and fixation of genes. Kadaknath birds are always in demand due to its meat quality, texture and taste. The birds are said to have some medicinal properties. Compared to demand, its availability is very low (Parmar et al., 2003). Literature on morphological and productive traits of the Kadaknath breed of poultry is scanty. Present study was undertaken to study the growth rate, feed conversion efficiency and carcass traits of Kadaknath breed of fowl upto five months of age under intensive system of housing.

How to cite this article: Dubey, P., Joshi, S., Chouhan, L., Mehta, M.K. and Shinde, A. (2021). Performance of Kadaknath Breed of Fowl Under Intensive System of Housing in Malwa Region of Madhya Pradesh. J. Anim. Res., 11(05): 881-884.

Source of Support: None; Conflict of Interest: None क्ष 


\section{MATERIALS AND METHODS}

Study was carried out on 500 straight run chicks of Kadaknath breed of fowl up to 5 months of age, under intensive system of housing (deep litter). The chicks were randomly distributed in four replications $\left(R_{1}, R_{2}, R_{3}\right.$ and $\mathrm{R}_{4}$ ) of 125 chicks each. The birds were fed with chick starter having 20\% Crude Protein and $2700 \mathrm{kcal} / \mathrm{kg} \mathrm{ME}$ and grower ration having $18 \%$ Crude Protein and 2500 $\mathrm{Kcal} / \mathrm{kg}$ ME. The average daily feed consumption, body weight, gain in body weight and feed conversion ratio (FCR) were recorded weekly up to eight week of age and thereafter at monthly interval upto 5 months of age. The individual birds were weighed at the end of each week upto 8 week of age and the total body weight gain per week was calculated by subtracting the initial weight of bird from the final weight attained during that particular week. After 8 week of age feed conversion ratio was recorded at monthly interval upto 5 month of age. The estimated weight of all dead birds was added in total live weight to correct the feed efficiency losses due to mortality.

At the end of the experiment five birds from each replicate were randomly selected for evaluation of dressed weight, cut-up yields (breast, thigh), giblet yield (liver, heart, and gizzard), organ weight (spleen, bursa and thymus) and abdominal fat. The birds were kept off feed for a period of twelve hours prior to slaughter. The carcass traits were expressed as $\%$ of live weight. The live weight of the birds was recorded before slaughter. For obtaining edible carcass yield, the carcass was weighed after removal of feathers, viscera, head and legs. The percent weight of edible carcass, different edible organs such as breast yield, thigh yield etc. was calculated over dressed weight.

Weekly mortality rate was also determined during entire experimental period. The mortality rate was expressed as percentage of all birds housed / procured during starting of the experimental period.

\section{RESULTS AND DISCUSSION}

\section{Feed consumption}

The weekly feed consumption recorded in Kadaknath birds from one to eight week of age ranged from $21.29 \pm 0.11$ to $244.52 \pm 2.82 \mathrm{~g}$ and the monthly feed consumption from 3 to 5 month of age ranged from $1682.09 \pm 38.59$ to 1622.83 $\pm 7.14 \mathrm{~g}$ (Table 1). Present findings are in agreement with those, reported by Gupta et al. (2000) in Aseel birds. However, previous studies have reported comparatively lower feed consumption in Kadaknath birds (Parmar et al., 2003; Jain et al., 2010). The analysis of variance revealed non-significant differences between replications, confirms the uniform management practices adopted during course of investigation.

\section{Body weight and weight gain}

The average weight of day old chicks was found to be $28.55 \pm 0.5 \mathrm{~g}$. ranging from $27.81 \pm 0.66$ to $29.04 \pm 1.25$ $\mathrm{g}$ in replication. The body weight increased linearly over age during the entire experimental period and the birds attained $974.28 \pm 17.96 \mathrm{~g}$ weight at 5 months of age (Table 1). The body weight so obtained in Kadaknath birds in present study is comparable to the findings of Sachdeva et al. (1990) in Kadaknath fowl. However, higher body weights at different ages have been reported in Thai Native birds (Siripholvat, 1999), Aseel and Kadaknath crosses (Gupta et al., 2006; Mondal et al., 2007) and in Kadaknath fowl (Sharma et al., 2012). Thakur et al. (2006) and Thakur and Parmar (2011) have reported lower body weight in Kadaknath birds. The variations observed among various studies could be partly attributed to genetic constitution of the birds. The weekly gain in body weight linearly increased from $7.54 \pm 0.10$ at one week of age to $86.34 \pm 5.65 \mathrm{~g}$. at 8 week of age. The rate of gain showed a reducing trend from fourth month onwards. The analysis of variance showed non significant differences between replications for all the age groups $(\mathrm{P}>0.05)$.

\section{Feed conversion ratio (FCR)}

Kadaknath birds are mostly reared for table purpose and hence, feed conversion ratio is an important economic trait in the birds which determines the overall profit. The FCR obtained in the present study ranged from $2.09 \pm$ 0.08 to $2.84 \pm 0.12$ from one to eight week of age. The FCR obtained at 3, 4 and 5 month of age was $6.46 \pm 0.06$, $9.97 \pm 0.37$ and $12.56 \pm 1.98$ (Table 1 ). The R4 replication exhibited poor FCR which could be attributed to the fact that there were more females in this replication group. The analysis of variance showed non-significant differences between the replications for most of the age groups $(\mathrm{P}>0.05)$, except for $3^{\text {rd }}, 4^{\text {th }}, 5^{\text {th }}$ weeks and 5 month of age. 
Table 1: Feed consumption, weight gain and feed conversion ratio (g)

\begin{tabular}{lllll}
\hline Age & Feed consumption $(\mathbf{g})$ & Body weight $(\mathbf{g})$ & Weight gain $(\mathbf{g})$ & Feed conversion ratio \\
\hline 1 week & $21.29 \pm 0.11$ & $36.10 \pm 0.31$ & $7.54 \pm 0.10$ & $2.82 \pm 0.35$ \\
2 week & $46.43 \pm 0.71$ & $52.95 \pm 0.53$ & $16.84 \pm 0.44$ & $2.75 \pm 0.09$ \\
3 week & $82.60 \pm 0.92$ & $85.18 \pm 1.45$ & $32.23 \pm 1.87$ & $2.56 \pm 0.05$ \\
4 week & $104.38 \pm 2.09$ & $127.60 \pm 3.06$ & $42.42 \pm 3.23$ & $2.46 \pm 0.05$ \\
5 week & $115.45 \pm 2.66$ & $178.49 \pm 3.63$ & $50.91 \pm 3.22$ & $2.26 \pm 0.03$ \\
6 week & $150.51 \pm 1.17$ & $250.80 \pm 9.57$ & $72.30 \pm 3.36$ & $2.09 \pm 0.08$ \\
7 week & $163.63 \pm 2.99$ & $321.38 \pm 5.70$ & $70.59 \pm 4.24$ & $2.32 \pm 0.13$ \\
8 week & $244.52 \pm 2.62$ & $407.73 \pm 3.18$ & $86.34 \pm 5.65$ & $2.84 \pm 0.12$ \\
3 Month & $1682.09 \pm 38.59$ & $668.30 \pm 6.59$ & $260.52 \pm 7.49$ & $6.46 \pm 0.06$ \\
4 Month & $1739.05 \pm 11.84$ & $842.87 \pm 10.11$ & $174.58 \pm 7.50$ & $9.97 \pm 0.37$ \\
5 Month & $1622.83 \pm 7.14$ & $974.28 \pm 17.96$ & $131.41 \pm 18.84$ & $12.56 \pm 1.98^{*}$ \\
\hline Overall & $\mathbf{5 9 7 3 . 1 2} \pm \mathbf{1 2 8 . 3 1}$ & - & $\mathbf{9 4 5 . 7 3} \pm \mathbf{4 7 . 2 2}$ & $\mathbf{6 . 3 1} \pm \mathbf{1 . 0 3}$ \\
\hline
\end{tabular}

The results obtained in the present study are in agreement with the findings of Gupta et al. (2000) in Kadaknath birds. Results obtained by Parmar et al. (2003) in Kadaknath birds reared in Jhabua district are comparable with present findings.

\section{Carcass traits}

The dressing percentage was found to be $70.43 \pm 1.79$ in Kadaknath birds slaughtered at 5 months of age. Similar finding have been reported in Aseel (Gupta et al., 2000), Kadaknath (Sachdeva, 1990; Parmar et al., 2003) and in Tellicherry chicken of Kerala (Kumar et al., 2013). Higher dressing percentages were reported in Thai Indigenous birds and fast growing varieties like Leghorn, RIR, Plymouth rock (Kongruttananun, 1992; Intharachote et al., 1996). The giblet yield in Kadaknath birds was $5.35 \pm$ $0.02 \%$ of live weight. These findings are comparable with the results obtained by Parmar et al. (2003) in Kadaknath birds at 23 week of age (7.7\%), by Kumar et al. (2013) in Tellicherry chicken of Kerala (6.03\%) and by Balaji et al. (2008) in broilers $(4.13 \%)$. The values recorded for breast muscle, thigh muscle, abdominal fat and weight of organs (spleen, thymus and bursa) were $19.41 \pm 0.13,14.91 \pm$ $0.25,1.59$ and $0.88 \pm 0.04$ percent, respectively. Parmar et al. (2003) and Kumar et al. (2013) recorded higher percentage of breast muscle. However, the proportion of this is comparable with present study. The abdominal fat recorded in present study was higher than those obtained by Parmar et al. (2003) in Kadaknath birds.

\section{Mortality}

An overall mortality of $25.2 \%$ was recorded during entire period of experiment. Maximum mortality was recorded during first week (11.4\%) followed by second week (2.6\%). Pandian et al. (2013) recorded mortality ranging from $3.01 \%$ to $56.58 \%$ during brooding and growing periods in White Leghorn, RIR and their crosses. During first week most of the chicks died due to yolk sac infection (11.4\%). Terregino et al. (2000) also observed yolk sac infection as one of the common causes of mortality in the first week of age. However, Sharma et al. (2005) reported higher deaths due to omphalitis, colibacillosis and pneumonia during first week of age in broilers. A higher mortality rate recorded during sixteenth week $(2.4 \%)$ was due to occurrence of fowl cholera and salmonellosis at this age.

\section{CONCLUSION}

Present findings establish the standards for Kadaknath on feed requirement under deep litter system. The feed conversion ratio was poor in Kadaknath birds as compare to fast growing birds. The breast muscle and edible organs of Kadaknath birds are in higher proportion whereas; abdominal fat is lower in comparison to fast growing birds. It is imperative from results that Kadaknath birds, as with other breeds, need extra care during first two weeks of brooding. The overall findings suggest that Kadaknath birds can perform well in Malwa region of M.P. 


\section{REFERENCES}

Balaji, K. 2008. Effect of dietary inclusion of azolla (Azolla pinnata) on production performance of broiler chicken. $\mathrm{M}$. V. Sc. Thesis submitted to Kerala Agriculture University. Thrissur, pp. 96.

Gupta, R.K., Mohan, S., Singh, U. and Gurung, B.S. 2000. Feed efficiency and carcass characteristics of Aseel chicken. Indian J. Anim. Sci., 70(11): 1170-1171.

Gupta, C.S., Kumar, A., Arya, R., Patel, M., Ghosh, A.K. and Palod, J. 2006. Growth performance of different crossbred chickens under backyard rearing. Ind. Vet. J., 83(8): 905-906.

Intharachote, U., Poonpipat, R. and Bunyanuwat, K. 1996. Growth and Carcass Quality of Native Crossbred Chickens. The $34^{\text {th }}$ Kasetsart Universtiy Annual Conf., 30 January -1 February 1993. p. 388-394.

Jain, A., Tomar, I. S., Tripathi, R.K. and Kumar, S. 2010. Effect of Different Levels of Protein on Growth Performance in Kadaknath Birds. Ind. J. Anim. Prod. Mgmt., 15: 45-47.

Kongruttananun, N. 1992. A study of Growth and Reproductive Development of The Native Compared with Those of Some other Pure-Breed Chickens. Master of Thesis, Kasetsart University, pp. 167.

Kumar, P.G., Churchil, R.R., Jalaludeen, A., Narayanankutty, K. And Kannan, A. 2013. Carcass characteristics of Tellicherry chicken raised under extensive production system. Ind. Vet. J., 90(6): 71-73.

Mondal, A., Patel, M., Kumar, B., Singh, A., Ghosh, A.K. and Bhardwaj, R.K. 2007. Performance of different crossbred chickens in intensive system. Indian J. of Poult. Sci., 42(2): 211-214.

Pandian, C., Omprakash, A.V.A., Sundaresan and Babu M. 2013. Mortality pattern in layers of an organised poultry farm. Ind. Vet. J., 90(5): 25-27.
Parmar, S.N.S., Shrivastava, P.N., Tomar, S.S., Pillai, P.V.A. and Tomar, I.S. 2003. Characterization of Kadaknath breed of poultry. JNKVV, Tech. Bulletin, DRS/2003/01.

Sachdev, A.K., Singh, D.P., Gopal, R. and Verma, S.S. 1990. Sex, live weight and dressed weight affecting carcass yield characteristics in Kadaknath. Indian J. Anim. Res., 60(11): 1395-1398.

Sharma, D.C. and Narayankhedkar, S.G. 2005. Carcass evaluation traits of crosses between Kadaknath breed of Indian native chicken, Rhode Island Red and White Leghorn. Ind. Vet. J., 82(2): 221-222.

Sharma, P., Tripathi, S.M., Vishwakarma, N., Jain, A. and Rai. H. S. 2012. Performance of Kadaknath and Krishna-J birds reared as backyard system of farming in Mandla District of M.P. Int. J. Livest. Res., 2(2): 241-244.

Siripholvat, V. 1999. Comparing the Genetic Parameter of Body Weight Estimated with 2 Methods in Thai Indigenous Chicken. Witthayasan Kasetsat, 33(3): 354-362.

Terregino, C., Catelli, E., Zanoni, R., Giordano, S. and Sanguinetti, V. 2000. Causes of early broiler chick mortality. Ravi.-di Avi., 69: 34.

Thakur, M.S., Parmar, S.N.S. and Pillai, P.V.A. 2006. Studies on growth performance in Kadaknath breed of poultry. Livest. Res. Rural. Dev., 18(116).

Thakur, M.S. and Parmar, S.N.S. 2011. Studies on growth pattern and gain in body weight in Kadaknath breed of poultry in their native breeding tract. J. Anim Res., 1: 21-27. 